\title{
ANALISA KEAUSAN DISC BESI COR DENGAN METODE MATEMATIKA SEDERHANA MENGGUNAKAN TRIBOMETER PIN-ON-DISC TANPA PELUMAS
}

\author{
Imam Syafa'at ${ }^{*}$, Abdul Khalim dan Darmanto \\ Jurusan Teknik Mesin, Fakultas Teknik, Universitas Wahid Hasyim \\ Jl. Menoreh Tengah X/22, Sampangan, Semarang 50236 \\ *Email: imamsyafaat@unwahas.ac.id
}

\begin{abstract}
Abstrak
Semakin maju dan berkembangnya ilmu pengetahuan dan teknologi di bidang mechanical engineering khususnya di bidang tribologi, maka akan semakin banyak terungkap faktor-faktor yang dapat mempengaruhi umur pemakaian komponen dari sebuah mesin. Besi cor adalah salah satu bahan untuk membuat komponen dari suatu mesin. Penelitian kali ini menggunakan tribometer pin-on-disc dengan besi cor A (79.5 HRB), besi cor B (82 HRB) dan besi cor A (86.5 HRB) sebagai disc dan bola baja AISI 52100 berdiameter $8,0 \mathrm{~mm}$ dengan kekerasan $60 \mathrm{HRC}$ sebagai pin. Penelitian ini bertujuan untuk mengetahui pengaruh penggunaan material disc dan ukuran diameter pin terhadap nilai lebar kontak keausan, koefisien keausan berdimensi, volume dan tinggi keausan yang terjadi pada besi cor. Kajian juga membandingkan hasil keausan dengan berbagai model yang yang telah ada sebelumnya. Analisa perhitungan menggunakan penurunan geometri berdasarkan rumus matematika dasar sederhana dan menggunakan metode penurunan persamaan Archard. Hasil penelitian menunjukkan bahwa lebar kontak keausan, koefisien keausan berdimensi $\left(K_{D}\right)$, ketinggian keausan $(h)$ dan volume keausan $(V)$ mempunyai hubungan berbalik nilai dengan kekerasan material dan senilai dengan jarak sliding (s). Ukuran diameter pin mempunyai hubungan sebanding dengan lebar kontak aus, koefisien keausan berdimensi $\left(K_{D}\right)$, ketinggian keausan (h) dan volume keausan (V). Semakin keras suatu material maka keausan yang terjadi akan semakin kecil.
\end{abstract}

Kata kunci: keausan, besi cor, pin-on-disc, Archard, metode sederhana

\section{PENDAHULUAN}

Berkembangnya ilmu pengetahuan dan teknologi di bidang mechanical engineering khususnya di bidang tribology, maka faktorfaktor yang dapat mempengaruhi umur pemakaian dari sebuah komponen mesin dapat diketahui. Tribology adalah ilmu pengetahuan dan teknologi yang mempelajari interaksi permukaan dalam gerakan relatif berkaitan dengan fenomena (gesekan dan keausan) yang terkait dengan fisika, mekanika, metalurgi dan kimia (Kajdas dkk, 1990). Interaksi yang terjadi biasanya akan menimbulkan keausan pada komponen mesin.

Keausan (wear) adalah hilangnya material dari permukaan yang bersinggungan di dalam gerakan relatif dikendalikan oleh sifat material, lingkungan, kondisi operasional dan geometri dari permukaan yang bersinggungan (Stolarsky, 1990). Untuk mengetahui besarnya keausan dapat dilakukan dengan metode penelitian secara eksperimental dengan menggunakan tribometer pin-on-disc. Gambar 1 memperlihatkan salah satu contoh komponen yang terjadi gesekkan dan pada akhirnya menimbulkan keausan. Gesekkan

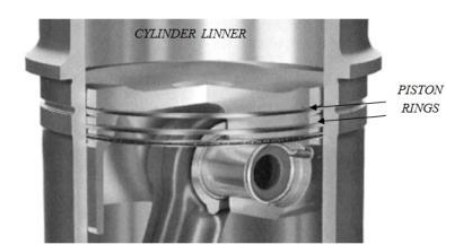

Gambar 1 Gesekan Piston Rings dengan Cylinder Liner (Anonim, 2014)

Pada Penelitian terdahulu yang telah dilakukan oleh Irfan (2017) tentang analisa keausan besi cor grafit bulat menggunakan tribotester pin-on-disc. Penelitian Irfan (2017) menggunakan ball bearing AISI 52100 dengan kekerasan $60 \mathrm{HRC}$ dan diameter 9,5 mm serta menggunakan material disc besi cor dengan kekerasan 79,5 HRB, 82 HRB dan 86,5 HRB dengan beban $10 \mathrm{~N}$ tanpa menggunakan pelumas. Dari penelitian ini didapatkan hasil bahwa semakin besar nilai kekerasan material maka semakin kecil nilai koefisien keausan berdimensi, tinggi dan volume keausan yang terjadi pada material tersebut. Berdasarkan uraian pendahuluan, maka penelitian sekarang dilakukan untuk mengetahui nilai lebar kontak aus, ketinggian keausan, koefisien keausan 
yang terjadi adalah antara piston rings dengan cylinder liner.

ukuran diameter yang berbeda pada pengujian keausan besi cor dengan kekerasan 79,5 HRB, 82 HRB dan 86,5 HRB dengan menggunakan tribometer pin-on-disc. Penelitian ini menggunakan matematika sederhana dan membandingkannya dengan model-model keausan yang telah ada sebelumnya.

\section{Kajian Teori \\ Besi Cor}

Besi cor adalah salah satu bahan yang sangat penting yang dipergunakan lebih dari $80 \%$ sebagai bahan coran. Pada umumnya besi cor mengandung $2 \%$ karbon atau lebih, tetapi dalam kenyataannya besi cor juga banyak mengandung $\mathrm{Si}, \mathrm{Mn}, \mathrm{P}, \mathrm{S}$ dan unsur-unsur lainnya (Surdia and Saito, 1999).

Secara umum besi cor dapat dikelompokkan menjadi empat yaitu:

1. Besi cor putih (white cast iron)

Besi cor putih mempunyai kandungan silikon di bawah 1\%, karbon antara 2,8-3,6\%.

2. Besi cor mampu tempa (malleable cast iron)

Pada umumnya besi cor mampu tempa merupakan besi cor putih yang sudah mengalami perlakuan panas pada temperatur $800^{\circ} \mathrm{C}$ dan $900^{\circ} \mathrm{C}$.

3. Besi cor kelabu (grey cast iron)

Besi cor kelabu adalah besi cor yang kandungan karbonnya bervariasi antara 2,5\% $4 \%$ sementara kandungan silikonnya antara $1 \%$ $3 \%$.

4. Besi cor bulat (nodular cast iron)

Besi cor jenis ini pada dasarnya termasuk dalam kelompok besi cor kelabu (grey cast iron). Perbedaan diantara keduanya terletak pada bentuk grafitnya. Grafit pada besi tuang kelabu berbentuk serpih (flake) sedangkan pada besi cor nodular grafitnya berbentuk bulat. Ini karena ada penambahan Mg ke dalam cairan besi cor (Surdia and Saito, 1999).

Adapun jenis-jenis besi cor bulat menurut JIS G 5502 adalah sesuai dengan Tabel 1.

Tabel 1 Spesifikasi Besi Cor Bulat atau FCD Sesuai JIS G 5502 (Sularso and Suga, 2004) berdimensi, volume keausan serta membandingkannya dengan penelitian Irfan (2017) untuk mengetahui pengaruh penggunaan

dan Brinell. Nilai kekerasan Brinell dapat dicari dengan menggunakan Persamaan (1).

$$
H B=\frac{2 P}{\pi D_{b}\left[D_{b}-\left(D_{b}-d_{b}^{2}\right)^{1 / 2}\right]}
$$

Dimana $\mathrm{H}_{\mathrm{B}}$ adalah nilai kekerasan brinell, $\mathrm{P}$ adalah berat beban yang digunakan, $\mathrm{D}_{\mathrm{b}}$ adalah diameter identor, $\mathrm{d}_{\mathrm{b}}$ adalah diameter lubang hasil injakan dari identor.

Menurut Callister (2001) hubungan antara kekuatan tarik dan kekerasan material khususnya brinell adalah sesuai dengan Persamaan (2).

$$
T S=3.45 \times H B
$$

Dimana $H_{B}$ adalah nilai kekerasan brinell, TS adalah kekuatan tarik.

\section{Koefisien Keausan Berdimensi $\left(K_{\mathrm{D}}\right)$}

Sebuah klasifikasi nilai koefisien keausan Berdimensi $\left(\mathrm{K}_{\mathrm{D}}\right)$ telah disajikan oleh Anton Van Beek seperti yang terlihat pada Tabel 2 untuk memberikan gambaran tentang nilai $\mathrm{K}_{\mathrm{D}}$.

Tabel 2 Klasifikasi Nilai Koefisien Keausan Berdimensi

\begin{tabular}{llc}
\multicolumn{3}{c}{$\left(\mathrm{K}_{\mathrm{D}}\right)($ Van beek, 2012) } \\
\hline \multicolumn{2}{c}{$\mathbf{K}_{\mathbf{D}} \mathbf{1 0}^{-\mathbf{9}} \mathbf{m m}^{\mathbf{2}} \mathbf{N}$} & kelas \\
\hline 0.0001 & -0.001 & 0 \\
0.001 & -0.01 & 1 \\
0.01 & -0.1 & 2 \\
0.1 & -1.0 & 3 \\
1 & -10 & 4 \\
10 & -100 & 5 \\
100 & -1000 & 6 \\
1000 & -10000 & 7
\end{tabular}

Material diklasifikasikan sebagai keausan keras bila nilai $K_{D}$ nya lebih kecil dari $10^{-9}$ $\mathrm{mm}^{2} / \mathrm{N}$. Jika nilai $K_{D}$ nya semakin besar maka menandakan material tersebut semakin lunak dan begitupun sebaliknya.

\section{Ketinggian Keausan (h)}

Ketinggian keausan adalah ukuran kedalaman bekas gesekan dengan pin yang terjadi pada disc. Ini sesuai dengan yang ditunjukkan Gambar 2. 


\begin{tabular}{ccc}
\hline Lambang & $\begin{array}{c}\text { Batas Mulur } \\
\left(\mathrm{kg} / \mathrm{mm}^{2}\right)\end{array}$ & $\begin{array}{c}\text { Kekuatan Tarik } \\
\left(\mathrm{kg} / \mathrm{mm}^{2}\right)\end{array}$ \\
\hline FCD 40 & 26 & 40 \\
FCD 45 & 30 & 45 \\
FCD 50 & 35 & 50 \\
FCD 60 & 40 & 60 \\
FCD 70 & 45 & 70 \\
\hline
\end{tabular}

\section{Pengujian Kekerasan Material}

Secara umum kekerasan material dapat didefnisikan sebagai suatu ketahanan material terhadap deformasi plastik atau deformasi permanen (Dieter, 1987). Metode yang dipakai dalam pengujian kekerasan material dalam penelitian ini adalah rockwell

Dalam penelitian ini untuk mencari nilai ketinggian keausan pada disc menggunakan beberapa persamaan diantaranya adalah: Persamaan (3) dari eksperimen sekarang, Persamaan (4) dari Archard (1953), Persamaan (5) dari Stachowiak (2005) dan Persamaan (6) oleh Kauzlarich dan Williams (2001).

$$
\begin{aligned}
h & =R-\left(R^{2}-\left(\frac{W}{2}\right)^{2}\right)^{0,5} \\
h & =K_{D} \cdot P \cdot S=\frac{K}{H} \cdot P \cdot S \\
h & =\frac{D}{2}-\frac{1}{2}\left(D^{2}-W^{2}\right)^{1 / 2} \\
h & =R-R \cos \beta 0
\end{aligned}
$$

Dimana $h$ adalah ketinggian keausan, $R$ adalah jari-jari pin, $W$ adalah lebar kontak aus, $K_{D}$ adalah koefisien keausan berdimensi, $H$ adalah kekerasan material, $K$ adalah koefisien keausan tak berdimensi $\left(K=K_{D} . H\right), P$ adalah tekanan kontak, $s$ adalah jarak sliding, $D$ adalah diameter pin, $\beta o$ adalah sudut antara lebar keausan dan titik tengah pin dan $\pi$ adalah Konstanta 3,141592 ..

\section{Volume Keausan}

Volume keausan adalah volume material yang hilang akibat terjadinya gesekan. Ini sesuai dengan yang diillustrasikan oleh Gambar 3.

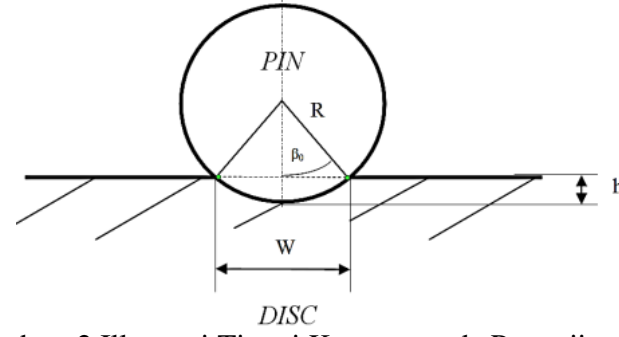

Gambar 2 Illustrasi Tinggi Keausan pada Pengujian Pinon-Disc

Selain menggunakan Persamaan (7), untuk mencari volume keausan dalam penelitian ini menggunakan Persamaan (8) dari Bayer (2004), Persamaan (9) dari Archard (1953), Persamaan (10) dari Sarkar (1980) dan Persamaan 11 dari Kauzlarich dan Williams (2001).

$$
\begin{aligned}
V & =\frac{\pi}{6} \times d \times \frac{W^{3}}{R} \\
V & =K_{D} \cdot F_{N} \cdot S=\frac{K}{H} \cdot F_{N} \cdot S \\
V & =K_{D} \cdot F_{N} \cdot S \cdot \sqrt{1+3 \mu^{2}} \\
V & =\pi \cdot K_{D} P \cdot N \cdot R^{3}
\end{aligned}
$$

Dimana $d$ adalah radius jalur pakai pada disc, $N$ adalah jumlah revolusi dan $\mu$ adalah koefisien gesek.

Adapun kosefisien gesek pada besi cor menurut Sularso dan Suga (2004) adalah sesuai dengan Tabel 3.

Tabel 3 Nilai Koefisien Gesek Besi Cor

\begin{tabular}{lcc}
\hline \multirow{2}{*}{ Bahan permukaan kontak } & \multicolumn{2}{c}{$\mu$} \\
\cline { 2 - 3 } & Kering & Dilumasi \\
\hline Besi cor dan besi cor & $0,10-0,20$ & $0,08-0,12$ \\
Besi cor dengan perunggu & $0,10-0,20$ & $0,10-0,20$ \\
Besi cor dan asbes (ditenun) & $0,35-0,65$ & - \\
Besi cor dan serat & $0,05-0,10$ & $0,05-0,10$ \\
Besi cor dan kayu & - & $0,10-0,35$ \\
\hline
\end{tabular}

\section{METODOLOGI}

\section{Alat dan Bahan}

Alat

Alat utama yang digunakan untuk penelitian keausan ini adalah tribometer pinon-disc. Alat ini adalah sesuai dengan yang diperlihatkan oleh Gambar 4. Adapun illustrasi kontak antara pin dan disc ditunjukkan oleh 


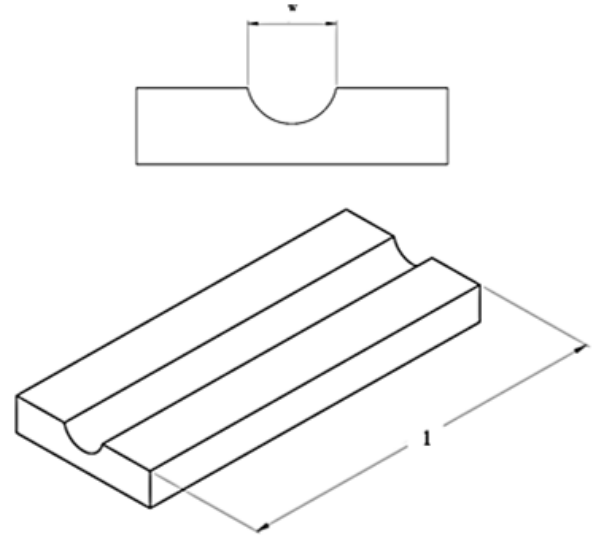

Gambar 3 Illustrasi Bangun Ruang dengan Alur Tembereng

Berdasarkan Gambar 3 dapat dicari volume alur tembereng yang merupakan volume keausan yang terjadi. Persamaan yang digunakan disamakan dengan mencari volume tabung karena keduanya mempunyai bentuk alas atas maupun bawah yang sama. Ini sesuai dengan Persamaan (7) (Anonim, 2013).

$$
V=A_{\text {Tembereng }} \times l
$$

Dimana $A_{\text {Tembereng }}$ adalah luas alas yang berbentuk tembereng dan $l$ adalah panjang alur.

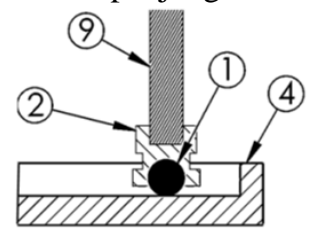

Gambar 5 Illustrasi Kontak antara Pin dan Disc

\begin{tabular}{lll}
\hline No & Nama & Kegunaan \\
\hline 1 & Pin & Uji keausan \\
2 & Holder & Pemegang pin \\
3 & Pemberat & Untuk mengatur beban \\
4 & Disc & Uji keausan \\
5 & Imverter & Mengatur kecepatan \\
\hline 6 & Lengan Beban & Penghubung antara beban dan beban penyeimbang \\
7 & Beban Penyeimbang & Menyeimbangkan beban \\
8 & Motor & Memutar disc \\
9 & Pemegang Holder & Penghubung antara holder dan lengan beban \\
\hline
\end{tabular}

Gambar 5.

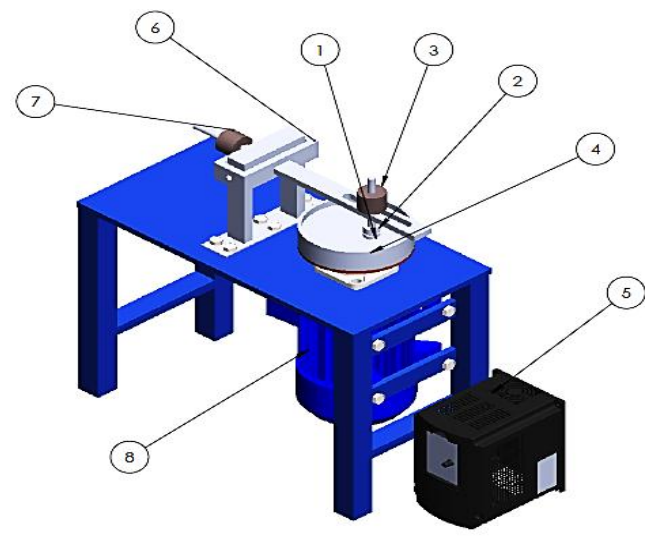

Gambar 4 Tribometer Pin-on-Disc
Gambar 5. Adapun langkah-langkah selanjutnya adalah sesuai dengan Gambar 6 .

Setelah melakukan langkah-langkah yang sesuai dengan Gambar 6 maka didapat jenis material disc yang digunakan yang sesuai dengan Tabel 4.

Tabel 4 Bahan Disc

\begin{tabular}{ccccc}
\hline Disc & $\begin{array}{c}\text { Rockwell } \\
(\mathrm{HRB})\end{array}$ & $\begin{array}{c}\text { Brinell } \\
\left(\mathrm{Kg} / \mathrm{mm}^{2}\right)\end{array}$ & $\begin{array}{c}\mathrm{TS} \\
\left(\mathrm{Kg} / \mathrm{mm}^{2}\right)\end{array}$ & Bahan \\
\hline Disc A & 79.5 & 148.9 & 52.3 & FCD 50 \\
Disc B & 82 & 157.7 & 55.5 & FCD 50 \\
Disc C & 86.5 & 171.4 & 60.3 & FCD 60 \\
\hline
\end{tabular}




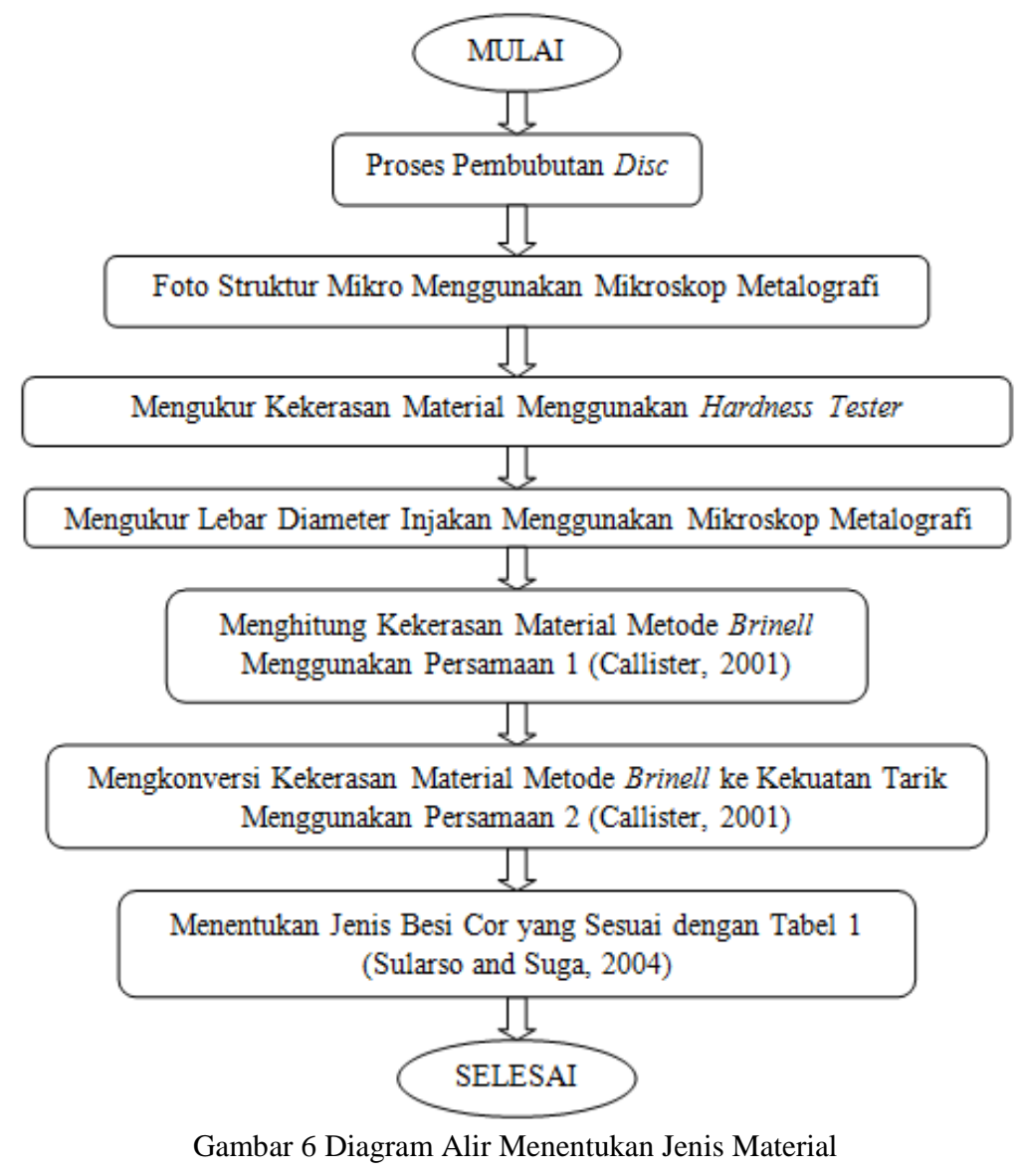

Bahan

\section{Bahan Pin}

Bahan pin yang digunakan dalam penelitian ini adalah bola baja AISI 52100 berdiameter 8,0 mm dengan kekerasan 60 HRC.

\section{Bahan Disc}

Untuk mengetahui jenis bahan yang digunakan sebagai disc maka bahan disc dibubut sehingga didapatkan ukuran diameter dan tebal sebesar $150 \mathrm{~mm}$ dan $27,30 \mathrm{~mm}$ yang sesuai dengan Gambar 4 dan
Dari Tabel 4 didapatkan informasi bahwa bahan disc A merupakan bahan yang paling lunak disusul oleh disc $\mathrm{B}$ dan disc $\mathrm{C}$.

\section{Alur Penelitian \\ Proses penelitian ini dimulai dengan melakukan studi pustaka kemudian dilanjutkan dengan pembuatan holder dan disc. Adapun langkah-langkah selanjutnya adalah sesuai dengan yang diperlihatkan oleh Gambar 7.}




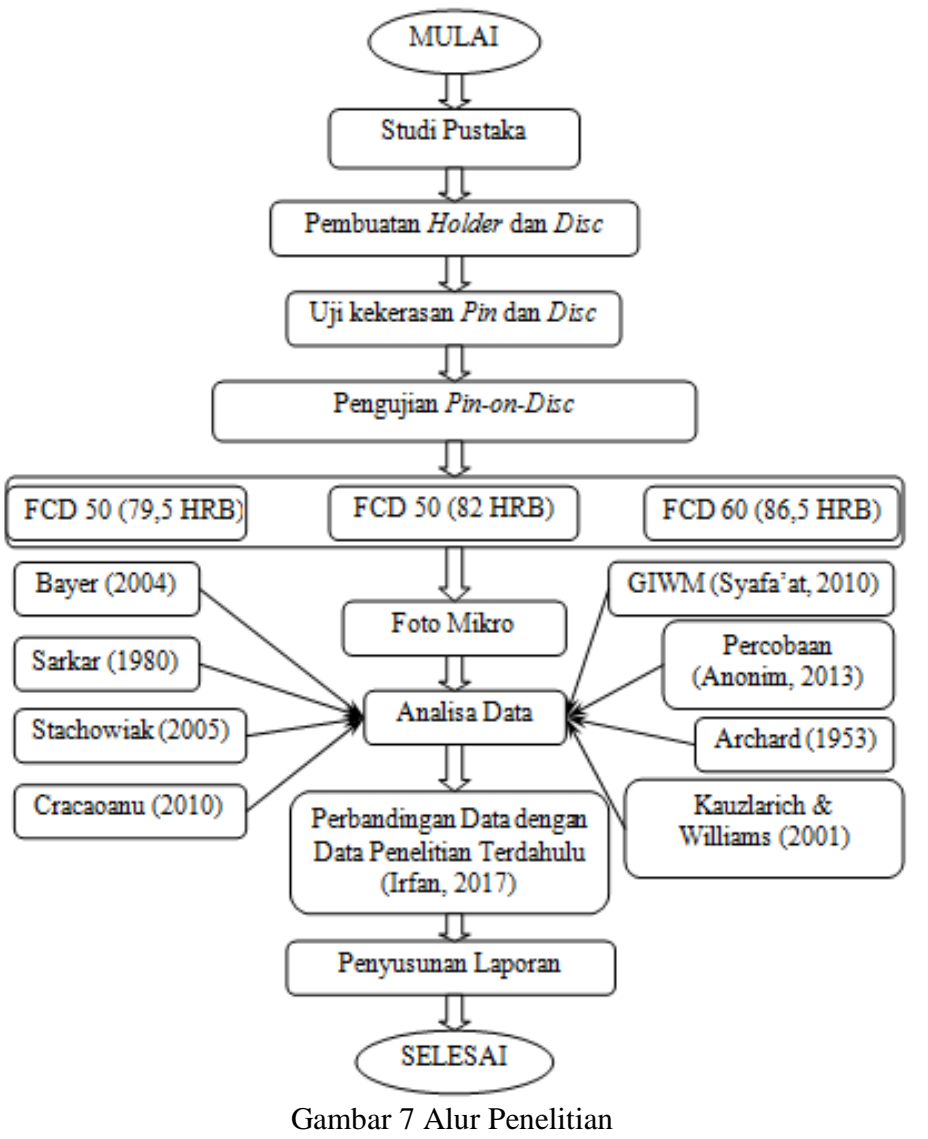

\section{HASIL DAN PEMBAHASAN}

\section{Hasil Pengujian}

Hasil pengujian keausan pada disc A yang telah diukur lebar kontak ausnya dengan menggunakan mikroskop metalografi adalah sesuai dengan Gambar 8.

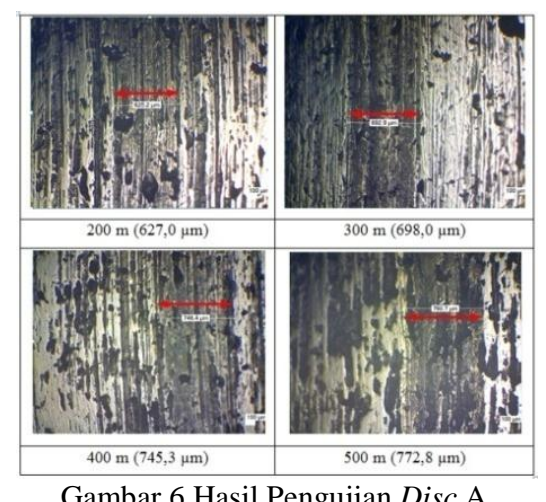

Berdasarkan Gambar 8 dapat diambil keterangan bahwa semakin panjang jarak sliding maka semakin besar nilai lebar kontak ausnya dan begitupun sebaliknya. Dari hasil pengujian yang dilakukan pada disc $\mathrm{A}$, disc $\mathrm{B}$ dan disc $\mathrm{C}$ dapat disajikan dalam sebuah grafik untuk mempermudah proses penganalisaan. Grafik tersebut adalah sesuai dengan Gambar 9.

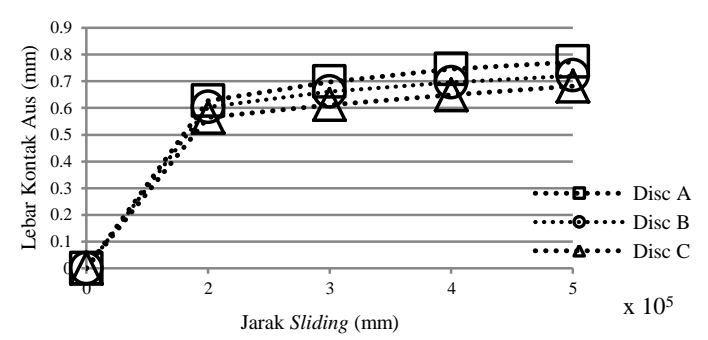

Gambar 9 Lebar Kontak Aus

Dari Gambar 9 dapat ditarik kesimpulan bahwa:

1. Lebar kontak aus mempunyai hubungan berbalik nilai dengan kekerasan material. Ini sesuai dengan yang diteorikan oleh Bayer (2004) dalam bentuk persamaan (lihat Persamaan 8). Dalam Persamaan 8 diperlihatkan bahwa lebar kontak aus (W) mempunyai nilai yang sebanding dengan volume keausan $(\mathrm{V})$. Sedangkan volume keausan (V) sendiri menurut Archard (1953) mempunyai hubungan berbalik nilai dengan kekerasan material $(\mathrm{H})$ (lihat Persamaan 9). Jadi jika kedua pernyataan tersebut digabungkan didapatkan pernyataan bahwa lebar kontak aus mempunyai hubungan berbalik nilai dengan kekerasan material.

2. Lebar kontak aus mempunyai nilai yang 
diperlihatkan bahwa lebar kontak aus (W) mempunyai nilai yang sebanding dengan volume keausan (V). Sedangkan volume keausan (v) sendiri menurut Archard (1953) dan Sarkar (1980) mempunyai nilai yang sebanding dengan jarak sliding (s) jika nilai koefisien keausan berdimensi $\left(\mathrm{K}_{\mathrm{D}}\right)$, beban normal $\left(\mathrm{F}_{\mathrm{N}}\right)$ dan koefisien gesek $(\mu)$ tetap (lihat Persamaan 9 dan Persamaan 10). Jadi jika kedua pernyataan tersebut digabungkan didapatkan pernyataan bahwa lebar kontak aus mempunyai nilai yang sebanding dengan jarak sliding (s). sebanding dengan jarak sliding. Ini sesuai dengan yang diteorikan oleh Bayer (2004) dalam bentuk persamaan (lihat Persamaan 8). Dalam Persamaan 8

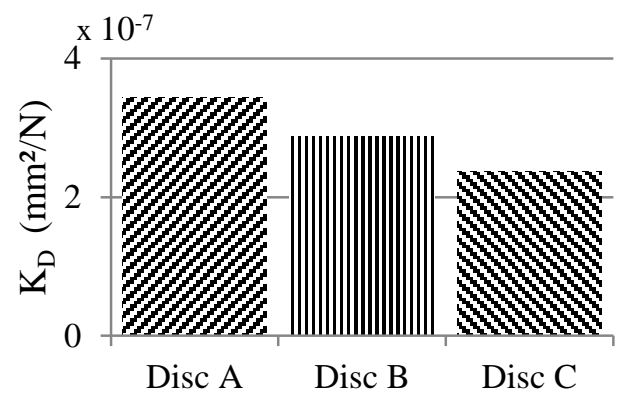

Gambar 11 Nilai Koefisien Keausan Berdimensi $\left(K_{D}\right)$

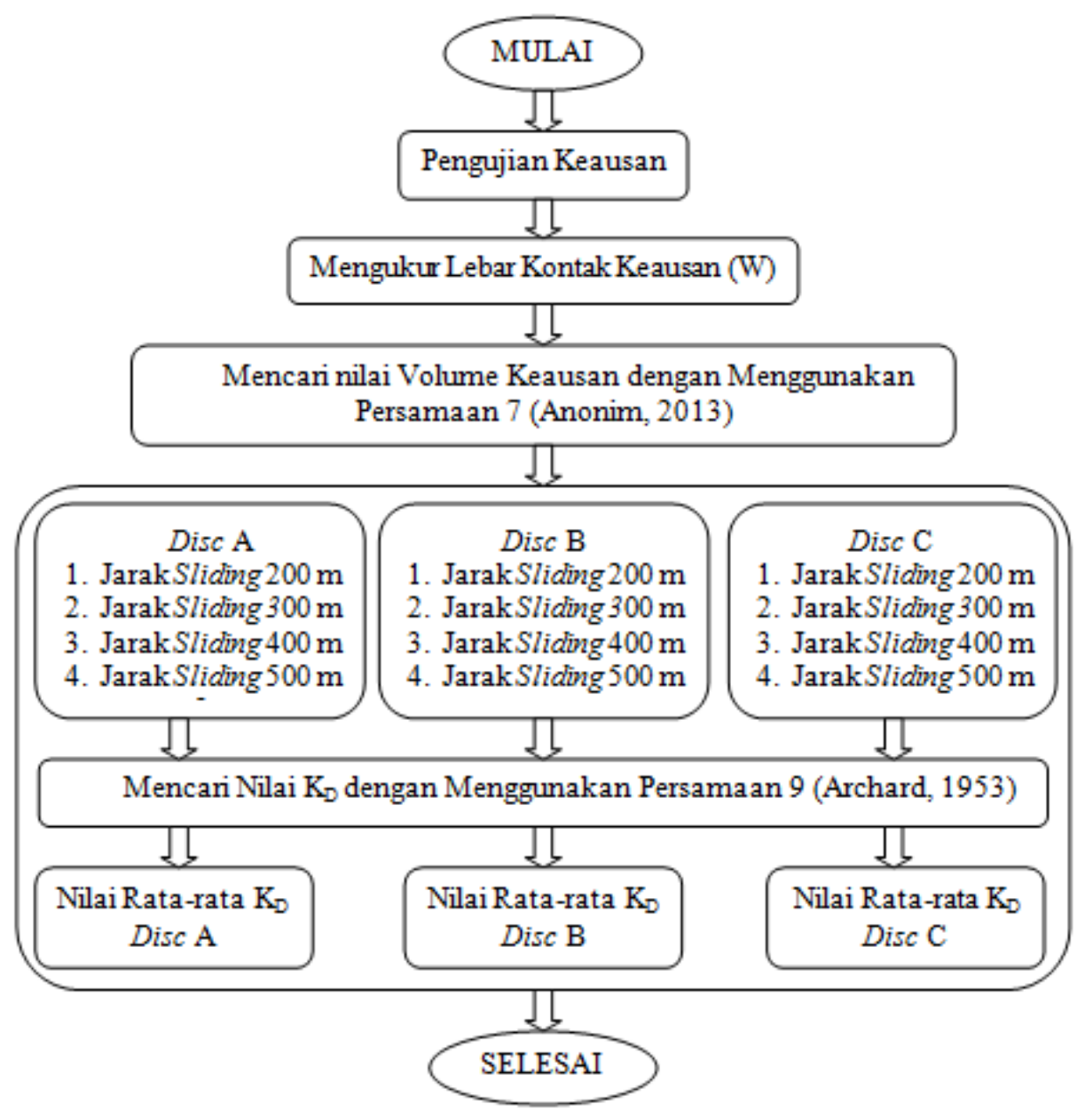

Gambar 10 Diagram Alir Mencari Nilai $K_{D}$

\section{Koefisien Keausan Berdimensi $\left(K_{D}\right)$}

Langkah-langkah untuk mencari nilai koefisien keausan berdimensi $\left(\mathrm{K}_{\mathrm{D}}\right)$ dimulai dengan melakukan pengujian keausan bahan disc dengan menggunakan tribometer pin-on-disc. Adapun langkah-langkah selanjutnya adalah sesuai dengan Gambar 10.
Dari Gambar 11 dapat ditarik kesimpulan bahwa kekerasan material $(\mathrm{H})$ mempunyai hubungan berbalik nilai dengan koefisien keausan berdimensi $\left(\mathrm{K}_{\mathrm{D}}\right)$. Ini sesuai dengan yang diungkapkan oleh Van Beek (2012) dan Archard (1953) dalam Persamaan 9 bahwa semakin keras material maka nilai koefisien 
Setelah melakukan langkah-langkah yang sesuai dengan Gambar 10, maka didapat nilai koefisien keausan berdimensi $\left(\mathrm{K}_{\mathrm{D}}\right)$ sesuai dengan Gambar 11.

\section{Ketinggian Keausan (h)}

Dengan menggunakan Persamaan 3, Persamaan 4, Persamaan 5, Persamaan 6 didapatkan nilai ketinggian keausan yang sesuai dengan Gambar 12. keausan berdimensinya akan semakin kecil dan begitupun sebaliknya.

berdimensi $\left(\mathrm{K}_{\mathrm{D}}\right)$, tekanan kontak $(\mathrm{P})$ tetap (lihat Persamaan 4).

Hasil perhitungan nilai ketinggian keausan (h) dengan menggunakan Persamaan 4 (Archard, 1953) mempunyai nilai yang berbeda jauh. Ini terjadi karena

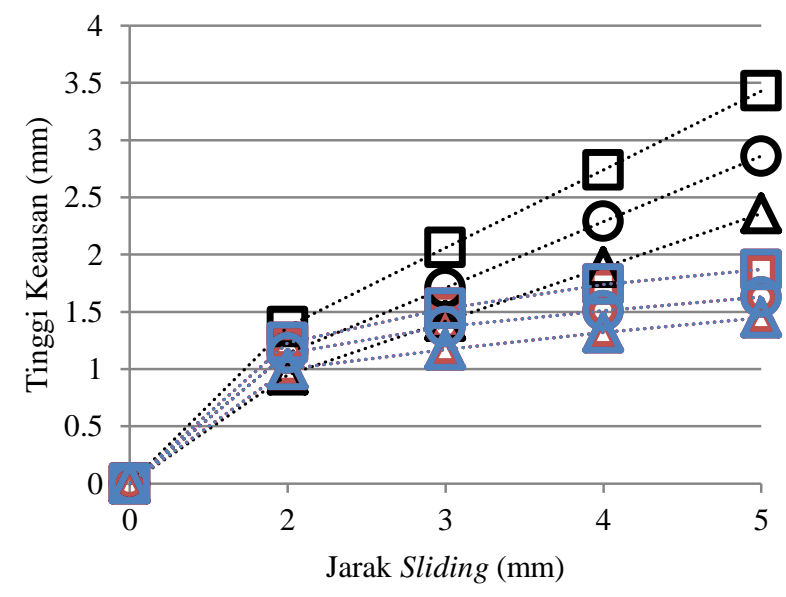

........ Percobaan Disc A

....... Percobaan Disc B

....... Percobaan Disc C

……. Archard Disc A

…... Archard Disc B

........ Archard Disc C

........ Kauzlarich \& Williams Disc A

…… Kauzlarich \& Williams Disc B

........ Kauzlarich \& Williams Disc C

........ Stachowiak Disc A

…… Stachowiak Disc B

....... Stachowiak Disc C

Gambar 12 Ketinggian Keausan

Dari Gambar 12 dapat diambil kesimpulan bahwa semua persamaan sepakat bahwa:

1. Nilai ketinggian keausan sebanding dengan jarak sliding. Ini sesuai dengan yang diteorikan oleh Archard (1953) yang mengatakan bahwa nilai ketinggian keausan sebanding dengan jarak sliding ( $\mathrm{s}$ ) jika nilai koefisien keausan berdimensi $\left(\mathrm{K}_{\mathrm{D}}\right)$ dan tekanan kontak $(\mathrm{P})$ tetap (lihat Persamaan 4).

2. Nilai ketinggian keausan berbanding terbalik terhadap kekerasan material. Ini sesuai dengan yang diteorikan oleh Archard (1953) yang mengatakan bahwa Nilai ketinggian keausan sebanding dengan jarak sliding (s) jika nilai koefisien keausan persamaan tersebut memasukkan nilai koefisien keausan berdimensi $\left(\mathrm{K}_{\mathrm{D}}\right)$ dan tekanan kontak (P) dalam mencari nilai ketinggian keausan. Sedangkan persaman yang lain proses perhitungan ketinggian keausan (h) hanya berdasarkan geometri semata yang menggunakan rumus persamaan matematika dasar yang telah dikembangkan.

\section{Volume Keausan (V)}

Dengan menggunakan Persamaan 7, Persamaan 8, Persamaan 9, Persamaan 10 dan Persamaan 11, maka didapat nilai volume keausan (V) sesuai dengan Gambar 13. 

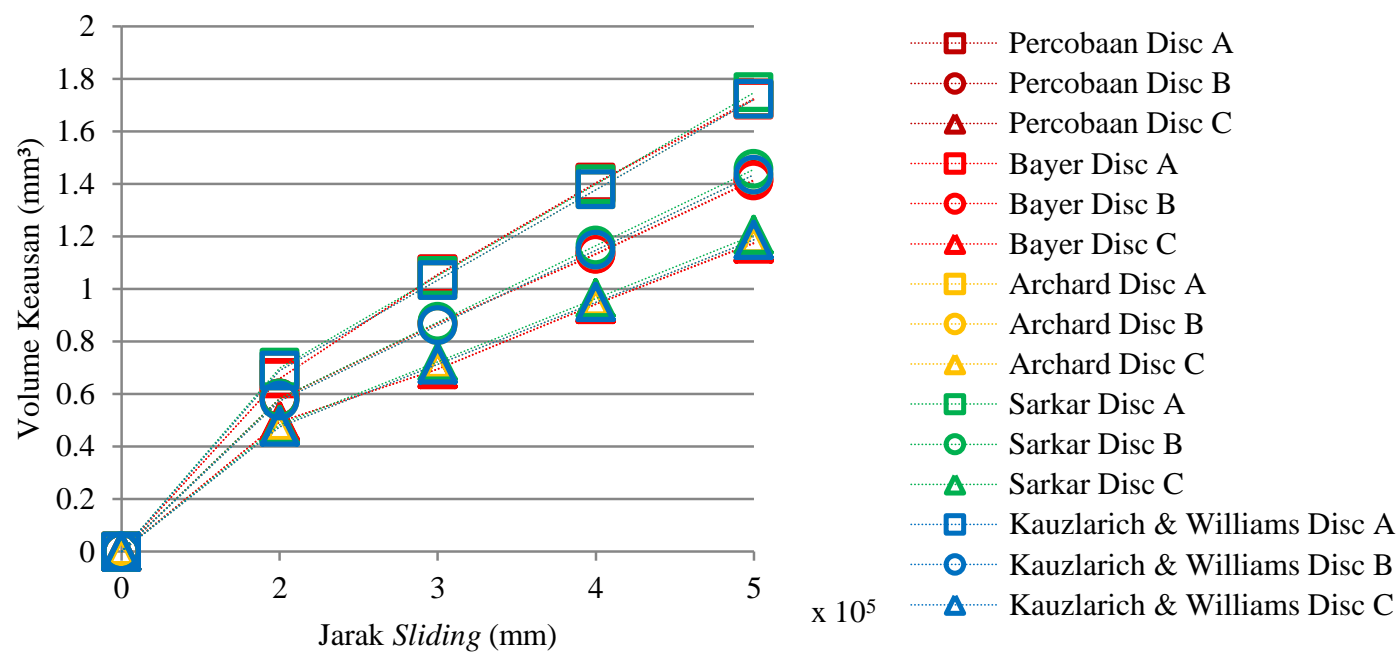

Gambar 13 Volume Keausan bahwa:

Dari Gambar 13 dapat diambil kesimpulan

1. Nilai volume keausan (V) sebanding dengan jarak sliding (s). Ini sesuai dengan teori yang dikemukakan oleh Archard (1953) dan Sarkar (1980) yaitu nilai volume keausan sebanding dengan jarak sliding (s) jika nilai koefisien keausan berdimensi $\left(\mathrm{K}_{\mathrm{D}}\right)$, beban normal $\left(\mathrm{F}_{\mathrm{N}}\right)$ dan koefisien gesek $(\mu)$ tetap (lihat Persamaan 9 dan Persamaan 10).

2. Nilai volume keausan (V) berbanding terbalik dengan kekerasan material. Ini sesuai dengan Archard (1953) yang mengungkapkan bahwa volume keausan mempunyai hubungan berbalik nilai dengan kekerasan material $(\mathrm{H})$ (lihat Persamaan 9).

3. Dari semua hasil perhitungan menggunakan menggunakan Persamaan 7, Persamaan 8, Persamaan 9, Persamaan 10 dan Persamaan 11 didapatkan hasil yang hampir sama. Ini menunjukkan bahwa semua persamaanpersamaan tersebut dapat digunakan untuk menghitung volume keausan yang terjadi pada disc.

\section{Perbandingan dengan Penelitian Terdahulu}

Penelitian terdahulu yang pernah dilakukan adalah analisa keausan besi cor grafit bulat menggunakan tribotester pin-on-disc (Irfan, 2017). Penelitian ini menggunakan jenis material disc dan jarak sliding yang sama dengan penelitian sekarang tetapi menggunakan ukuran diameter pin yang berbeda. Penelitian Irfan (2017) menggunakan pin dengan diameter 9,5 mm sedangkan pada penelitian sekarang menggunakan ukuran diameter pin sebesar 8,0 $\mathrm{mm}$.

1. Lebar Kontak Aus
Dari Gambar 14 dapat diambil kesimpulan bahwa lebar kontak aus memilik nilai yang sebanding dengan ukuran diameter pin. Ini terjadi karena pin merupakan benda yang digunakan untuk menggores dalam simulasi keausan ini. Jadi jika pin atau dalam hal ini sebagai penggoresnya besar maka hasil goresannya atau dalam hal ini disebut sebagai lebar kontak aus juga semakin besar pula ukuran dimensinya. Ini juga sesuai dengan yang diungkapkan oleh Kauzlarich dan Williams (2001) bahwa jari-jari pin mempunyai nilai yang sebanding dengan volume keausan (lihat Persamaan 11) jika nilai koefisien keausan berdimensi $\left(\mathrm{K}_{\mathrm{D}}\right)$, tekanan kontak $(\mathrm{P})$ dan jumlah revolusi $(\mathrm{N})$ bernilai tetap/konstan. Sedangkan lebar kontak aus memiliki nilai yang sebanding dengan volume keausan (Bayer, 2004) atau sesuai dengan Persamaan 8. Jadi kalau diambil kesimpulan dari pernyataan keduanya adalah lebar kontak aus memilik nilai yang sebanding dengan ukuran diameter pin.

\section{Koefisien Keausan Berdimensi}

Dalam penelitian yang telah dilakukan oleh Irfan (2017) untuk mencari nilai koefisien keausan berdimensi $\left(\mathrm{K}_{\mathrm{D}}\right)$ menggunakan acuan nilai volume keausan berdasarkan Persamaan 8, kemudian menyubtitusikan hasil persamaan tersebut ke dalam Persamaan 10. Sedangkan pada penelitian sekarang nilai koefisien keausan berdimensi $\left(\mathrm{K}_{\mathrm{D}}\right)$ didapat dari hasil perhitungan nilai volume keausan menggunakan Persamaan 7 kemudian menyubtitusikan hasil persamaan tersebut ke dalam Persamaan 9 (lihat Gambar 10).

Oleh karena itu untuk melakukan perbandingan dengan penelitian Irfan (2017) 
Dari hasil penelitian Irfan (2017) dan Gambar 9 dapat disajikan dalam sebuah grafik untuk mempermudah proses penganalisaan tentang perbandingan nilai lebar kontak aus. Ini sesuai dengan Gambar 14. hendaknya menghitung kembali nilai koefisien keausan berdimensi $\left(\mathrm{K}_{\mathrm{D}}\right)$ dengan metode yang sama dengan yang digunakan Irfan (2017).

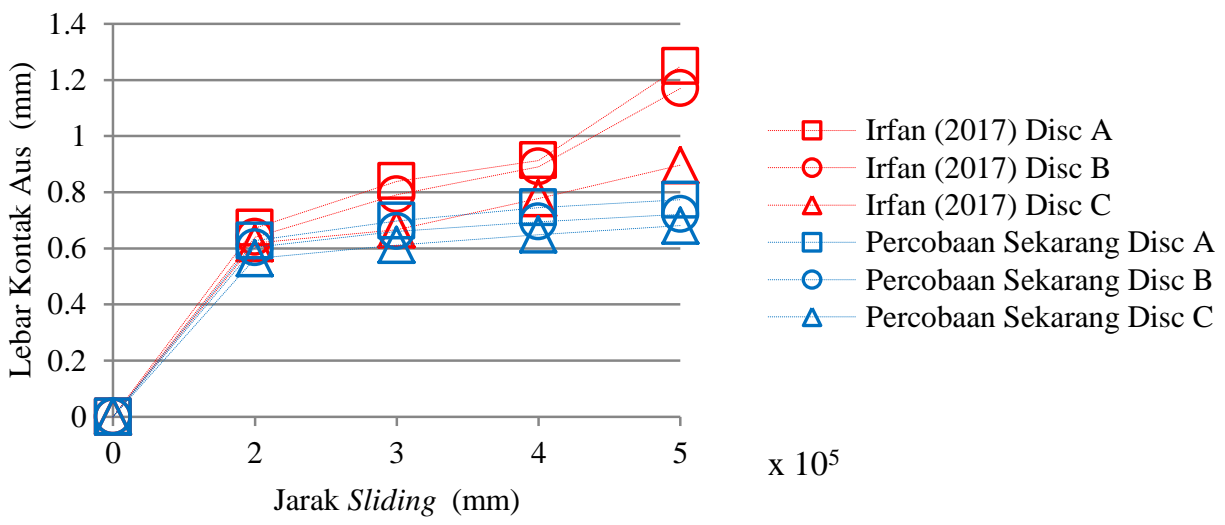

Gambar 14 Perbandingan Lebar Kontak Aus

Berdasarkan Gambar 11, hasil perhitungan nilai $K_{D}$ penelitian Irfan 2017) dan hasil perhtungan nilai $K_{D}$ metode Bayer penelitian sekarang dapat dibuat dalam sebuah grafik untuk mempermudah proses penganalisaan tentang perbandingan nilai koefisien keausan berdimensi $\left(K_{D}\right)$. Ini sesuai dengan Gambar 15.

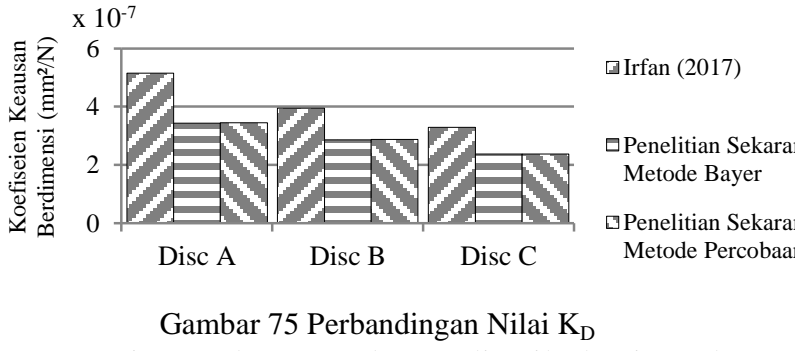

Dari Gambar 15 dapat ditarik kesimpulan bahwa ukuran diameter pin mempunyai nilai yang sebanding dengan nilai $\mathrm{K}_{\mathrm{D}}$. Ini terjadi karena menurut Kauzlarich dan Williams (2001) semakin besar jari-jari pin maka volume keausan yang terjadi semakin besar (lihat Persamaan 11) jika nilai koefisien keausan berdimensi $\left(\mathrm{K}_{\mathrm{D}}\right)$, tekanan kontak (P) dan jumlah revolusi (N) tetap. Sedangkan menurut Archard (1953) semakin besar nilai volume keausan (V) maka semakin besar pula nilai koefisien keausan berdimensinya $\left(\mathrm{K}_{\mathrm{D}}\right)$ jika besar beban normal $\left(\mathrm{F}_{\mathrm{N}}\right)$ dan jarak sliding (s) tetap (lihat Persamaan 9).
Nilai $K_{D}$ penelitian Irfan (2017) dan penelitian sekarang berbeda tetapi jika diterapkan dalam Tabel 2 masih dalam klasifikasi sekelas dengan hasil pengujian Irfan (2017).

Ini terjadi karena material yang sama pasti mempunyai nilai $\mathrm{K}_{\mathrm{D}}$ yang sama atau masih dalam rentan sekelas dalam klasifikasi nilai $\mathrm{K}_{\mathrm{D}}$ walaupun metode perhitungan untuk mencari nilai $\mathrm{K}_{\mathrm{D}}$ berbeda yaitu metode Bayer dan metode percobaan.

\section{Ketinggian Keausan}

Perbandingan ketinggian keausan hanya dilakukan pada ketinggian keausan dengan menggunakan Persamaan 3 dengan ketinggian keausan percobaan pada penelitian Irfan (2017).

Berdasarkan hasil penelitian Irfan (2017) dan Gambar 12 dapat disajikan dalam sebuah grafik untuk mempermudah proses penganalisaan tentang perbandingan nilai ketinggian keausan. Ini sesuai dengan Gambar 16.

4. Volume Keausan

Perbandingan volume keausan hanya dilakukan pada volume keausan dengan menggunakan Persamaan 8 (Bayer, 2004) dengan volume keausan hasil penelitian Irfan (2017) serta melakukan perbandingan pada hasil penelitian sekarang yaitu antara hasil perhitungan hasil volume keausan dengan menggunakan Persamaan 7 dan Persamaan 8. 


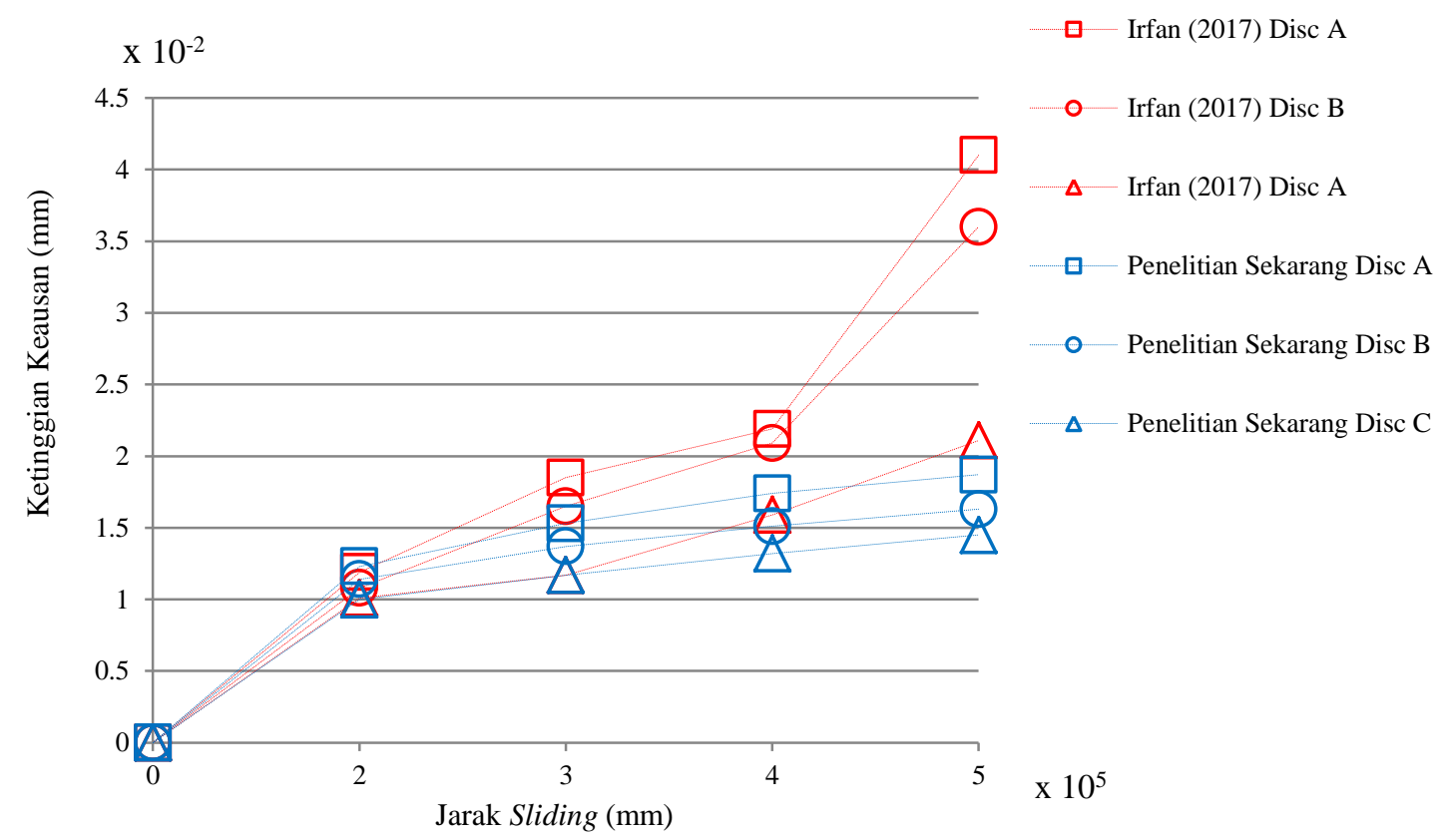

Gambar 16 Perbandingan Nilai Ketinggian Keausan

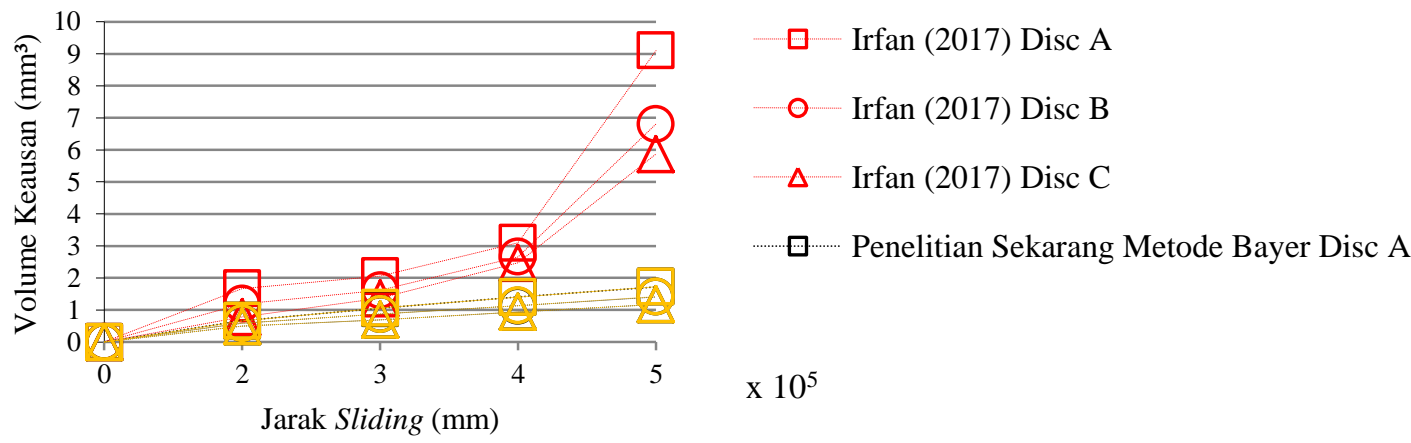

Gambar 17 Perbandingan Nilai Volume Keausan

Berdasarkan hasil penelitian Irfan (2017) dan Gambar 13 dapat disajikan dalam sebuah grafik untuk mempermudah proses penganalisaan tentang perbandingan nilai volume keausan. Ini sesuai dengan Gambar 17. Dari Gambar 17 juga dapat diambil kesimpulan bahwa ukuran diameter memilik nilai yang sebanding dengan volume keausan. Ini sesuai dengan Kauzlarich dan Williams (2001) yang menyatakan bahwa diameter pin mempunyai nilai yang sebanding dengan volume keausan (V) (lihat Persamaan 11).

\section{KESIMPULAN}

1. Lebar kontak keausan, koefisien keausan berdimensi $\left(\mathrm{K}_{\mathrm{D}}\right)$, kedalaman keausan $(\mathrm{h})$ dan volume keausan $(\mathrm{V})$ mempunyai hubungan
Irfan, M. (2017). Analisa Keausan Besi Cor Grafit Bulat Menggunakan Tribotester Pin-on-disc. Semarang: Tugas Akhir Universitas Wahid Hasyim.

Kajdas, C., Harvey, S. S. K., Wilusz, E. (1990). Encyclopedia of Tribology Vol 15. Dalam Encyclopedia of Tribology Vol 15 (hal. 364). Elsevier.

Kauzlarich, J. J., Williams, J.A. (2001). Archard Wear and Component Geometry. Proceedings of the Institution of Mechanical Engineers, Part J: Journal of Engineering Tribology, Vol. 215, hal 387403.

Sarkar, A. D. (1980). Friction and Wear, Academic Press, London.

Stachowiak, G. W. (2005). Tribology in 
berbalik nilai dengan kekerasan material dan mempunyai hubungan senilai dengan jarak sliding ( $\mathrm{s}$ ).

2. Ukuran diameter pin mempunyai hubungan sebanding dengan lebar kontak keausan, koefisien keausan berdimensi $\left(\mathrm{K}_{\mathrm{D}}\right)$, ketinggian keausan (h) dan volume keausan (V).

\section{DAFTAR PUSTAKA}

Anonim (2013). www.informasipendidikan.com.

Anonim. (2014). www.motogokil.com.

Archard, J. F. (1953). Contact and rubbing of flat surfaces. J. Appl. Phys., 24, 981-988

Bayer. R. G. (2004). Mechanical Wear Fundamentals and Testing, Second Edition, Marcel Dekker, Inc. New York.

Callister Jr, W. D. (2001). Material Science and Engineering an Introduction Fifth Edition. New York: John Willey and Sons.

Dieter, G. (1987). Metalurgi Mekanik Jilid I Edisi Ketiga. Jakarta: Erlangga. practice series, in Wear-Material, Mechanisms and Practice, John Wiley \& Sons Ltd, The Atrium, Southern Gate, Chichester, England.

Stolarsky, T. A. (1990). Tribology in Machine Design. Butterworth-Heinemann, Oxford. Great Britain

Sularso dan Suga, K. (2004). Dasar Perancangan dan Pemilihan Elemen Mesin. Jakarta: Pradnya Paramita.

Surdia, T., Saito, S. (1999). Pengetahuan Bahan Teknik. kajdasJakarta: Pradnya Paramita

Van beek, A. (2012). Advanced Engineering Design: Lifetime Performance and Reliability. TU Delft. Delft. 